\section{THE EAST INDIA COMPANY: THE FIRST MODERN MULTINATIONAL?}

A popular parlour game among historians is debating when the modern world began. Was it when Johannes Gutenberg invented the printing press, in 1440? Or when Christopher Columbus discovered America, in 1492? Or when Martin Luther published his 95 theses, in 1517? All popular choices. But there is a strong case to be made for a less conventional answer: the modern world began on a freezing New Year's Eve, in 1600, when Elizabeth I granted a company of 218 merchants a monopoly of trade to the east of the Cape of Good Hope.

The Economist, December 17, 2011

In many ways the EIC was a model of corporate efficiency: 100 years into its history, it had only 35 permanent employees in its head office. Nevertheless, that skeleton staff executed a corporate coup unparalleled in history: the military conquest, subjugation and plunder of vast tracts of southern Asia. It almost certainly remains the supreme act of corporate violence in world history. For all the power wielded today by the world's largest corporations - whether ExxonMobil, Walmart or Google - they are tame beasts compared with the ravaging territorial appetites of the militarised East India Company. Yet if history shows anything, it is that in the intimate dance between the power of the state and that of the corporation, while the latter can be regulated, it will use all the resources in its power to resist.

William Dalrymple, The Guardian, March 4, 2015
Commented [US1]: -affiliation and adress of the coauthors are missing

-Abstract(not more than 100 words) and Keywords (up to 6 words) are missing

-Source p. 6 is not in the references

-A source listed in the references is not quoted in the text

Stewart Clegg, University of Technology Sydney Business School, Dr Chau Chak Wing Building, Building 8, 14 - 28 Ultimo Road, Ultimo,NSW 2001, Australia; also a Visiting Professor at Nova School of Business and Economics,

Lisbon, Portugal and Strategic Research Advisor at

Newcastle University Business School, Newcastle, UK

\title{
Introduction
}

The Roman Catholic Church must be considered the world's first multinational corporation. While The Church's concerns were ostensibly more spiritual than material its role in plundering the mineral riches of the Americas to decorate its churches ensured an economic dimension. However, the East India Company can lay claim to being the world's first company whose operations involved systematic organization of multiple countries focused substantially more on material rather than spiritual relations. As The Economist (2011), in posing the origins of the modern world, goes on to say

The East India Company foreshadowed the modern world in all sorts of striking ways. It was one of the first companies to offer limited liability to its shareholders. It laid the foundations of the British empire. It spawned Company Man. And - particularly relevant at the moment-it was the first state-backed company to make its mark on the world ...

Given that the East India Company was one of the world's first multinationals a key research question must be what kind of multinational it was and to what extent 
did it prefigure more contemporary forms of multinational enterprise? Drawing on historical evidence and discussion and relating these to contemporary accounts of multinationals, this chapter will seek to answer these questions. It will be argued that, despite its archaism, many elements of the template for multinational management and organization were first established during the career of the East India Company. As Robins (2006) argues, the East India Company pioneered the model of the corporation that we see today. Its innovations included the shareholder model of ownership, and the administrative framework of the modern firm.

\section{The East India Company}

Foundations

The East India Company was a monopoly, licensed by the state ${ }^{1}$. Under its Charter, granted by the Crown in December 1600, the merchants who constituted the East India Company enjoyed a monopoly on the direct trade in goods between England and East Asia. The East India Company was founded initially as an import/export company. From the headquarters in London 'supercargoes' were dispatched as the basis for trade under the control of the 'factors' that accompanied them, to be traded either from the ships that set sail or from 'factories' that were established on land as trading posts.

The factors were the earliest multinational managers. They had a great deal of complexity to manage. Given their international business operations there was significant spatial separation of their peripheral business units from the centre of operations in London with geographical, political, socioeconomic, cultural and religious boundaries framing these peripheral actors and actions, far from the centre of affairs in London. Given the limitations of contemporary communications the factors were highly autonomous. They were institutional entrepreneurs in a very literal sense: they had to make up the rules of global trade as they constructed it. It would take between four to six months for any despatch to arrive from London and it could only travel as the southwest monsoon allowed its vessel to round the Cape of Good Hope and blow the sails northeast from May to October. Reporting back to head

\footnotetext{
${ }^{1}$ One general history of the East India Company is John Keay's (1993) weighty The Honourable Company: A History of the East India Company. More economical is The Guardian Podcast Audio Long Read by the redoubtable historian of India, William Dalrymple (2015), titled 'The East India Company: The original corporate raiders'.
} 
office was equally as onerous: one could only set sail during the northeast monsoon between November and April. Surveillance of the periphery by the centre was virtually impossible under these circumstances.

Considerable seamanship, comprising knowledge of coastal geography, seasons, currents, winds and seaworthy passages, was necessary to make the hazardous journey. A strong constitution was required, especially in transit through the 'Roaring Forties'. Initially, the East India Company's agents sought mimetic isomorphism: their initial forays were made in the wake of established Portuguese and Dutch traders. Initially they sought to cut into the spice trade that the Dutch dominated from their foothold in Bantam, Java. Bantam was situated at the mouth of the Banten River, which provided a navigable passage for light craft into the island's interior and that was strategically close to the Sunda Strait through which ships sailed between Java and Sumatra.

The Dutch and the Portuguese had already secured landfall at the most propitious sites for the spice trade. The best niches were already occupied, hence the East India Company's early forays into the spice trade were to prove unsuccessful, finding their egress and trading opportunities effectively blocked by the competition from the Netherlands: the Vereenigde Oost-Indische Compangie or Dutch East India Company. They were no more successful in the China trade, initially, or in Japan, where their early foothold near Nagasaki lasted only a few years. As Foster (1933) suggests, it was less design and more default that turned the endeavours of the company to the Indian subcontinent.

The Dutch East India Company was the pioneer in terms of systematic European trade with Asia but they copied the East India Company's organizational structure. In their earliest voyages, a company was set up for the duration of a single voyage only, and was liquidated upon the return of the fleet. Such voyages were very risky. Piracy, disease and shipwreck were misadventures that might befall the ship. Should the ship make it safely back to Rotterdam with a cargo of spices from the Spice Islands that we now know as present day Indonesia the success of the venture would depend on market forces. Inelastic demand and relatively elastic supply of spices made for highly speculative profits. If two rival ships were landed in the same season prices could tumble; if ships were lost at sea and one made it to harbour then the investors would be price makers. 
The particular insight of the East India Company was to manage these risks through forming a cartel that created a monopoly enterprise in 1600 , thereby threatening their Dutch competitors with ruin (De Vries \& Van der Woude, 1997). The Dutch response was relatively swift. Two years later the Dutch government followed suit, sponsoring the creation of a single "United East Indies Company", to which it granted a monopoly over the Asian trade. The charter of the new company empowered it to build forts, maintain armies, and conclude treaties with Asian rulers. It was licensed for 21 years, with a financial accounting only at the end of each decade (De Vries \& Van der Woude 1997). Initially, the two monopolies competed against each other in the East Indies spice trade. However, in 1623 the torture and execution by the Dutch of ten men in the service of the East India Company for treason, conspiring against Dutch interests on the island of Amboyna, which was at that time the centre of Dutch interests, led to the English quitting the far east Indies and refocusing activities on the Indian subcontinent.

\section{Competition and containment}

The Indian subcontinent was not a blank space. One of the largest empires and civilizations of that time confronted the factors once they had made landfall in India: the Mughal Empire. Nor were they the first Europeans to seek a niche as a coastal enclave. The Portuguese had arrived there first at Surat in the Mughal Subah of Gujarat. To make landfall the agents of the East India Company had first to defeat a Portuguese squadron moored at Swally Hole, the deep-water anchorage for Surat.

To trade in Gujarat was subject to strict conditions. They had to gain a firman or decree from the Emperor that allowed them to trade. Extensive politics circumscribed their business: while they were permitted a factory in which they could live and from which they could conduct trade they were subject to strict limits on access to resources. They could not buy property; they were kept distant from the river, the main conduit for traffic, because of fear of both their everyday behaviours defiling local customs centred on the practice of Islam in the mosque close by the river by literal as well as fear of ritual pollution (Hiromu 2009, p. 221). The everyday life of the factors and their English employees was quite primitive: until the mideighteenth century they lived in tents on the beach (Hiromu 2009, p. 203), so offence was easily given and taken. 
Expatriate managers and employees lived in a hellhole, according to contemporary accounts. Being an expatriate was no lotus life: the risks were plenty and included dysentery, hepatitis, malaria, cholera and plague, with the attractions limited to the sex and drugs available. Of the former there was a plentiful supply: the prostitutes who serviced the Company lived adjacent in thatched huts while the drugs of choice included lashings of rum and toddy. Alcohol, sexual relations with prostitutes and etiquette - or the lack of it - associated with toilet functions were main causes of local offence taken with these infidels.

From the vantage point of Surat the factors strove to establish the rules of the game of trade as they wished to define them. Essentially, this meant establishing competitive advantage by whatever means were available, often through quite intense conflicts from which they sought to emerge as victors or treaty partners.

Opportunities beckoned: in 1614 two members of the company trekked overland to Isfahan, the seat of the Shah of Persia, via Khandahar in Afghanistan. The Shah sought to treat with them by offering them free trade in return for their alliance against the Portuguese whose fortress and emporium at Hormuz dominated the Hormuz straits at the mouth of the Persian Gulf. An alliance of convenience, or at least a coalition of interests ensued, linking the strategies of the Shah and the Company (Kalyvas, 2006, p. 383). By 1622 the Company delivered on the alliance: a joint Anglo-Persian attack levelled the fortress. The Company's reward was the granting of a factor at Bandar Abbas and a half share in the control of customs revenues flowing through it as a port city. The major trade was in silk (Darwin 2012, p. 53).

From their strategic vantage point in the Gulf the Company sought to compete with its rivals, notably the Dutch. It did so by establishing itself in what is now Tamil Nadu, in modern Chennai, known at that time as Madras, where they established Georgetown, centred on Fort St George, which was to remain the major trading post until the middle of the eighteenth century. The Company's commercial presence was literally hedged in. Foreign direct investment was allowed the Company only in the form of a lease of a territory limited to five miles frontage on the coast and one mile's depth into the interior. By mid-century 300,000 people lived in the leasehold (Wheeler, 1861, p. 252, cited in Darwin, 2012, p. 55). 
Amongst the 300,000 people wedged into the trading zone very few were expatriate staff: only twenty-seven were Company men, although there was a garrison of some 300 or so men. The European's in the Company's territory were not wholly English: they numbered Iberian Jews, Armenians and Portuguese, such that the quasicolony had a multicultural flavour. But overall, the culture was one of Little England, centred on the Anglican church of St Mary's, the consumption of typical imported English foodstuffs and beverages, the favouring of Anglo dress codes for Company employees, supplemented by prodigious consumption of brandy, plus the adoption of some local habits: concubinage, chewing betel nuts and smoking hookahs. Life lived within the enclave was one of constant awareness of the risks of blockade or attack.

\section{Alliances}

The reality of life under pressure was the necessity of alliances with locals. Alliances are, for everyone involved in them, a means rather than an end. The point of an alliance is to achieve something or other. Negotiations between political coalitions create the ordering of goals in organizations (March, 1962). Such negotiations can criss-cross organizations: they may occur at the departmental level, around specific strategic projects or over specific strategic issues. Interests that might align on one occasion will not necessarily cohere on another. When the power elites surrounding them changed their alliances changed. The institutional frame of life in the enclave was determined as much by adaptation to local conditions as by the import of alien custom, dress, food and religion. For instance, the British were lenient in their punishment of misdemeanours according to the local criminal code, which caused occasional offence. The enforcement of that code was allied with the norms of locals employed as adhikari or 'law men' but tempered by British norms.

Strategies decided at the centre, in this case in London, may order goals but they cannot always ensure their implementation in far-flung corners of the organizational empire. Sometimes the strategic centre of an organization can be at a great distance, in knowledge terms, from those places where implementation occurs: this often happens in organizations that have subsidiaries, despite strong central direction. The blocking, modifying and avoiding of central directives is sometimes a way of maintaining the discretion to adapt, creatively, what might not otherwise work locally (Sharpe, 2001; Becker-Ritterspach et al, 2002: see Dörrenbächer \& Geppert 2009 , p. 203). For instance, according to Company rules, traders were supposed to 
trade only within the remit of the Company. Evidently this was not the case: although it practised a mock bureaucracy of enforcement the rule was honoured as much in the breach as in the stipulation. As Darwin (2012, p. 57) explains, at least two of the governors made colossal fortunes in Madras, including a native of Boston,

Massachusetts, who was titular founder of Yale University as well as a forebear of William Pitt (the Younger), a future British Prime Minister, whose fortunes were thus founded.

To look at strategy as it is formulated at the centre is to look only at the centripetal controls: we need also to consider the centrifugal forces (Morgan, 2001). Recognizing that organizations, especially where they are large, complex and multinational, will be simultaneously subject to centripetal control and centrifugal forces, should ensure that we recognize the reality of strategic interests and micro-politics in the making of strategic practices. What is at issue is how certain practices become crucial in determining what is considered to be a strategic interest. Some actors will have micro-political skills that ensure certain positions are blocked and certain others advanced in terms of the strategic agenda (Johnson et al, 2003). Today, this is referred to in the literature as 'issue-selling': the strategies through which subsidiaries translate issues to be understandable by the parent company, thus enrolling them to act with respect to the issue. Successfully doing this allows the subsidiary to increase its bargaining power, in terms of the subsidiary's future ability to influence or shape parent-company decision-making (Luo, 2005). Theoretically, subsidiary bargaining power typically increases the more the parent company depends on resources it controls; where the subsidiary is able to legitimize its existence and behaviour, and when there is a close and personal relationship between decision makers at the parent and in the subsidiary company. The East India Company satisfied the first two of these criteria and could safely ignore the third because of the geographical and temporal distance at which the factors worked from investors in the city of London (Gammelgaard, 2009).

Strategy and public policy

Central corporate political strategies that seek to affect the public policy environment in a favourable way (Baysinger, 1984) are a major part of the strategy arsenal. Vernon (1971) suggested that, strategically, multinational companies (MNCs) with substantial investments would seek to influence host-country government 
policies to protect earnings and produce a favourable regulatory environment. The East India Company certainly confirmed to this strategy. The Company could not help but be a quasi-public actor because its activities were a highly intrusive form of politicization in the pre-modern territories in which it operated. Its presence created unintended side effects of economic imperialism for which there was a lack of any global regulation. As Young (2003, p. 40) suggests, 'agents are responsible for injustice by virtue of their structural connection to it, even though they are not to blame for it'. It was largely through the bribery and corruption of local regimes that the Company operated and established locally favourable regulatory regimes. The Company yielded economic, social, and political power comparable to the power of modern nation states. It assumed political responsibilities of tax raising and defence that once were governmental responsibilities. Theoretically, it is significant to note that the Company assumed these legitimate governmental functions not through attaining isomorphism with the existing institutional frameworks of the territories in which it operated but through their systematic subversion and corruption.

From the mid-1740s onwards, the Company's strategic concerns were advanced not so much through trade but through war and allied diplomacy. The host country ruler, the Mughal Emperor in Delhi, had become little more than a symbol due to events in Europe. In 1744 Britain and France were at war over Austria and thus the balance of European power. The French, who had a base in Pondicherry, launched an attack and seized Madras in 1746. Although peace was declared in 1748 and the British recovered Madras an undeclared war continued in South India. The Madras garrison was strengthened with 2,000 men, including 500 Swiss mercenaries. Local allies were bribed and threatened and strategic alliances forged with local princes. In return for military services rendered the Company began to acquire extensive revenue rights over increasing swathes of territory. The Company sought little consensus with subject peoples in terms of formally respecting traditional customs and values (cognitive legitimacy). In terms of the improvements of public works, such as port facilities, there was some attempt to seek legitimacy by contributing to the public good (pragmatic legitimacy). On the whole, however, legitimacy was bought and fought for, bribed and imposed. The pursuit of such legitimacy is fragile and dependent on the flow of bribes and the balance of force as a political strategy.

The choice of political strategies depends on the bargaining power of MNC subsidiaries compared to that of the host-country (Blumentritt, 2003). Boddewyn and 
Brewer (1994) argue that host governments represent both strategic risks and opportunities: governments may appropriate value from MNCs but they can also protect it (e.g., Boddewyn, 1975; 1988; 1993; Moran, 1985; Rugman \& Verbeke, 1993; Eden \& Molot, 2002). In 1756 protection turned to expulsion as the Nawab of Bengal expelled the company from the lucrative factory that it had established in Calcutta through which fine cotton fabrics passed for resale in Europe. Company employees were put to death; others were imprisoned, the fort was overrun. But the company now had an army: the balance of power and strategic advantage with the host government of the Nawab was changing. Under the command of General Clive the Nawab's forces were defeated at Plassey and within ten years the Company effectively controlled not only the territory but also the revenues of the province. Within forty years, Company men ruled in Delhi. An Indian empire, with modest mercantile origins, was born.

\section{The East India Company and its shifting mandate}

Any MNC comprises a highly complex configuration of ongoing micropolitical power conflicts at different levels. Social actors and groups inside and outside the firm interact with each other and create temporary balances of power. Sometimes external organizations can succeed in changing organizational mandates. Mandates are tasks that are assigned to subsidiaries by headquarters or that are acquired independently by the subsidiary, which have a specific time and content limitation placed on them, framing the internal division of labour within a MNC. The division of labour of the East India Company was changing. It was no longer a Company of traders so much as a de facto government after 1765 when the Company assumed the right to collect revenue (diwani) in return for a fixed payment to the Mughal Emperor, Shah Alam. Not only did the Company become a tax collector it also created a military organization that fought wars against existing states in order to extend its control up the Ganges valley and inland from Madras, where it fought against Mysore, a 'rising state' (Darwin, 2012, p. 77).

Within a few years, 250 company clerks backed by the military force of 20,000 locally recruited Indian soldiers had become the effective rulers of Bengal. An international corporation was transforming itself into an aggressive colonial power (Dalrymple, 2015). 
Mandates relate directly to the control of resources and the steering of potential actions; hence, mandates bestow different propensities for exercising power (Cyert \& March 1963; Pfeffer \& Salancik 1974; Birkinshaw \& Ridderstråle 1999). When mandates change there is immense potential for conflict within MNCs because the relative power relations of the different subsidiaries and the centre change in consequence. Any change can be simultaneously a process of downgrading and upgrading: as one subsidiary shifts to more or less demanding task all others change relatively in their relations with each other and the centre (Dörrenbächer \& Gammelgaard, 2006). Shifts in these relativities can translate directly into changes in status, careers, and incomes, things often hard fought for.

In the best traditions of enterprise the Company privatised profits while socializing losses. In 1770, 'famine wiped out a third of the population of Bengal, reducing local productivity, depressing the Company's business and eventually forcing it to go cap in hand to the British government to avoid bankruptcy' (The Economist, 2011). Despite this setback, the Company grew from having a monopoly of trade to becoming the tax-collector expropriating surplus from the peoples of India, a commercial organisation ruling 90m Indians, controlling 70 million acres $(243,000$ square kilometres) of land, issuing its own coins, complete with the Company crest, supporting an army of 200,000 men, all of which the East India Company did by 1800.

In the case of the East India Company the shift in mandate began to sound alarms in London. What was the constitutional status of a company that waged war, controlled territory and seemed to act according to no agenda directed from London? The fear was that the company was getting too big, too ambitious, in its Indian strategies: if it over-extended and its finances failed, the Company's Directors feared something akin to another South Sea Bubble - catastrophic financial failure that could ruin the British economy. A formal reframing of mandate ensued, culminating in the India Act of 1784. A Board of Control was established in London, reporting to a cabinet minister, who now oversaw its Indian budgets for Bombay, Madras and Bengal as well as its external military policy and choice of Governor-General. This changed mandate and system of control was maintained until the Company's abolition in 1858 when these controls were assumed by the British government through the establishment of the India Office (Darwin, 2012, p. 77). 


\section{Changing contexts}

The strategic options open to a MNC are always framed within specific contextual factors. A mix of national institutions, economic structures, resources and foreign investment policies of the country that is host to the investments made frame the context of operations. In the case of the East India Company the context was that territory bequeathed by a feudal grant from the Mughal Emperor for which they initially paid tribute, before declaring sovereignty over these territories that it ruled after 1800. The most pertinent national institutions were the weakness of the Mughal Emperor and the treaties that were struck with local Indian rulers. The status of these rulers was vague as to whether they were allies or subjects. While the remit of British law ran through the Company in principle, in practice there was much observance of local customs. Given the small number of Company men and the great mass of Indians whose beliefs were so entrenched in religions alien to British Anglicanism, interference in cultural practices threatened disorder, especially given the wide variance in custom from one religion to another.

The balance of power does not always lie with the centre, with the MNC headquarters. As Dörrenbächer and Gammelgaard (2006, p. 209) suggest, 'a careeroriented subsidiary manager', especially an expatriate, may well manage to decline mandate requests from headquarters where they calculate that there is a career advantage in doing so. The loyalties of expatriates will usually differ from those of host country nationals or third country nationals, with the assumption usually being that expatriates are more loyal to headquarters (Harzing, 1999). This was not necessarily the case in the East India Company: as remarked, fortunes were there to be made and were made by entrepreneurship that often exceeded the company's bounds.

In MNCs the majority of politics around the strategy process relate to mandated change in headquarters/subsidiary relations (Crozier \& Friedberg, 1980; Dörrenbächer \& Gammelgaard 2006, p. 206). The India Act of 1784 stated that 'to pursue schemes of conquest and extension of dominion in India are measures repugnant to the wish, the behaviour and the policy of this nation' (Keith, 1922, p.111; cited in Darwin, 2012, p. 124). Mandates, however, shift as contexts shift. What transformed the mandate of the East India Company were 'the rise of Napoleon, his invasion of Egypt in 1798 and the prospect of French help for Tipu Sultan, the dynamic ruler of Mysore and an inveterate enemy of the British' (Darwin, 2012, 
p.125). Mysore was invaded and Tippu killed in 1799 and the French threat receded when their navy was defeated in Egypt and their forces retreated. Although one balance of power was settled, between Britain and France, the balance in India was made more precarious. Mysore entered into a period of warfare with the Maratha Empire between 1785 and 1818. In the general weakening of continental power the company increasingly filled the role of broker and kingmaker, using military force where necessary.

How Company managers in India managed or ignored these local pressures was not a matter for calculation at the corporate centre while it posed real challenges for central governance. The Company in London was mostly unable to manage these struggles and the challenges that arose, given the complexity of local environments. In such a context the Company's servants, especially officers in the military, profited greatly from booty and plunder. 'On this frontier of empire, it was often hard to distinguish the private interest from the public' (Darwin, 2012, p. 126).

Power, legitimacy, resources and centrality in the East India Company's strategy

To be implemented any mandated change needs to accrue legitimacy. Legitimacy has been defined as 'a recognized perception or assumption that the actions of an entity are desirable, proper, or appropriate within some socially constructed system of norms, values, beliefs and definitions' (Suchman, 1995, p.574). The process of legitimization involves far more than merely developing an agreed strategy at the top level of the organization that the strategy team regards as appropriate or desirable: it also means implementing it, even against resistance.

Implementation is complex and difficult in any MNC because it is an internally differentiated set of intra-organizational and extra-organizational linkages in which resources are constantly being exchanged. The complexity of the networks makes it difficult for any nodal point in the network to know where the most critical resources reside. The fact that a strategic mandate may be set centrally does not necessarily minimize the creative and positive resistance of the margins; suggest Bouquet and Birkinshaw (2008, p. 491). Subsidiaries can develop new products and markets as the Company did in the opium trade with China, over which it had a 
monopoly until $1833 .^{2}$ Radically, the company's managers in India were constantly innovating and, on occasion, seeking to 'break the rules of the game' (Markides, 2000). The capacity to break the rules of the game depends on the structural relations that prevail within corporate empires. A great deal of corporate action is simultaneously decentralized and linked to corporate strategy. Local actors will use the resources that the global centre provides to seek local advantages over local rivals while using indigenes to tap into networks and mobilize resources that they would not otherwise access. A predictable outcome of such power games is politicization, which ensues when the games played by key actors undermine established rules of the game and patterns of domination. This was certainly the case in the East India Company, where the agents had considerable field autonomy, creating the institutional field in which international trade flourished. The emerging institutional field comprised a 'network of relations, micro-politics and capillaries of power' (Clegg et al 2006, p. 254), in which the rules of the emerging games were not just constraints but also enabled the key players building the field in India to play political games against both local rulers, competitors and the principals in London (see also Dörrenbächer \& Geppert, 2009).

\section{Exploiting new business opportunities}

The development of the nineteenth century China trade in opium is a case in point of local actors of the company using local resources to access new markets. The Indian Mutiny -the Great Rebellion - of 1857 threatened legitimacy most dramatically. Despite a standing army of 250,000 men on the Indian subcontinent a further 90,000 soldiers of the British Army were sent to restore control. After the Great Rebellion, in 1858, the British government took over all administrative duties in India. The Company's headquarters in London, East India House, was demolished in 1862 and its last dividend paid in 1873. Thus an organisation that had been given life by the state was eventually extinguished by it.

Successful strategy in a foreign market means that an enterprise must be better at doing what it does than any potential competition not otherwise excluded.

Comparative advantage might come into play: for instance, Afghanistan is well-suited ${ }^{2}$ Julia Lovell's (2011) The Opium War: Drugs, Dreams and the Making of China is an outstanding
history of this particular episode in the various wars that have been fought over the drug trade. 
to growing poppies and has a population used to producing opium for processing into heroin with local social institutions, such as powerful regional warlords represented in the Afghan government that enable the crop to flourish and be traded internationally, despite its stigma. The East India Company, at least until 1833, was deeply involved in the opium trade with China, in which they had a monopoly up until 1834, using opium as a substitute form of payment for valuable silver traded for Chinese goods. The Company encouraged people to use opium in China, as a result of which millions of Chinese died from opium addiction. Inadvertently, the grounds for both the commercial success of the barren and rocky island of Hong Kong, claimed as a British Crown Colony after the first Opium War of 1839-1842, (granted as such by the Treaty of Nanking of August $29^{\text {th }}$ that year), as well as the subsequent disintegration of society in China that ensued as a result of the opium trade, were sown by the East India Company.

\section{Comparative political advantage}

Comparative advantage can explain a few things about strategy in areas of primary production where the raw materials are simply not globally available just anywhere, such as the opium processed from Afghan poppies. Outside of these special cases it does not explain much. Comparative advantage is not merely a result of national factor endowments: it is the development of social institutions that provide the comparative advantage. For the East India Company these social institutions grew out of two core competencies: the ability of the directors in London to manage politicians, both at home and abroad; the ability of the Company to treat with, traduce and tax opposition to its will.

Politicians down the ages have been easily managed and the Company, untroubled by Independent Commissions Against Corruption, provides the prototype:

It meant getting close to courtiers who wanted to extract revenue from it and exposing itself to politicians who wanted to rewrite its charter. The Whig revolutionaries who deposed James II in 1688 briefly promoted a competing outfit that the Company first fought and eventually absorbed. Rival merchants lobbied courtiers to undermine its monopoly. But for the most part it dealt with these political problems brilliantly ... The Company created a powerful East India lobby in Parliament, a caucus of MPs who had either directly or indirectly profited from its business and who constituted, in Edmund Burke's opinion, one of the most united and formidable forces in British politics. It also made regular gifts to the Court: "All who could help or hurt at Court," wrote Lord Macaulay, "ministers, mistresses, priests, were kept in good 
humour by presents of shawls and silks, birds' nests and attar of roses, bulses of diamonds and bags of guineas." It also made timely gifts to the Treasury whenever the state faced bankruptcy. In short, it acted as what George Dempster, a stockholder, called a "great money engine of state".

The Company was just as adept at playing politics abroad. It distributed bribes liberally: the merchants offered to provide an English virgin for the Sultan of Achin's harem, for example, before James I intervened (The Economist, 2011).

Proffering English virgins to Sultan's and not being able to deliver on the goods may have been politically embarrassing but it serves to underline the extent to which the strategies of the Company were tangled up with complexities that were quite distinct from those that domestic traders might have encountered. As Morgan (2011, p. 416) suggests, 'the specific process of organizing and coordinating activities across the borders of distinctive national institutional contexts creates a new and distinctive level of complexity in social and organizational relations'. Different practices, processes, actors and what Morgan refers to as 'legitimatory discourses' pertain across different national settings. The East India Company managers had to manage the transfer of institutional practices that were legitimate in the home base coming into conflict with local institutional practices and sometimes the wrong choices are made: English virgins were not for trade. Certain institutional dualities are negotiable; others are not; nonetheless, they are pervasive and must be managed, creating a 'transnational social space' (Morgan, 2011) in which hybrid norms emerge, some of which may be quite problematic for the home base even while utterly acceptable in the local institutional context. The necessity of bribery and the purchase of favours in order to secure business in certain markets, many of them those pioneered by the Company, remains an issue to this day.

\section{Comparative military advantage}

Bribes and influence were one soft face of power, used to buy conditional consent, deployed freely at home and in India, where bankrupt rulers could usually be bought to deliver commercial access; if needs be the hard edge of power could also be deployed where consent was withdrawn or turned into resistance and it was used increasingly as the Company became more institutionalized. In this respect, Clive's victory at Plassey in 1757 became the petard with which it hoisted itself. While it delivered the government of Bengal to the Company and produced a guaranteed income from Bengal's taxpayers it made the Company not so much a trader as ruler. 
Once Bengal fell into the Company's remit it innovated new competitive strategies. Destroying the competition created markets. The basis on which it established the 'technological superiority' of the British textile industry was by 'systematic destruction of India's indigenous industry', not only through the artillery of cheap prices, as Marx wrote in Capital, but also through innovative competitive strategies such as the severing of the thumbs of master weavers in Bengal [and] forced cultivation of indigo by Bihar's peasants', as Banerjee (2008: 52) notes.

Much as any feudal monarch bent on conquest, raising revenue increasingly became its first priority. The adjunct of a secure revenue base was a cowed and contained populace. The instrument of containment was armed force. As The Economist writes:

Tax rolls replaced business ledgers. Arsenals replaced warehouses. C.N. Parkinson summarised how far it had strayed, by 1800, from its commercial purpose: "How was the East India Company controlled? By the government. What was its object? To collect taxes. How was its object attained? By means of a standing army. What were its employees? Soldiers, mostly; the rest, Civil Servants" (The Economist, 2011).

It might be tempting to read the history of the Company as a component part of some overall rational strategy of imperialism pursued by the British government. It might be tempting but it would be mistaken. As Darwin (2012, p. 389) states, the British empire 'was in the main a private enterprise empire' in which the 'role of the state was largely confined to the granting of charters that conferred commercial monopoly or jurisdictional power on companies or proprietors ... this was an empire of commercial experiments not an empire of rule by design'.

\section{Comparative efficiency advantage}

MNCs must be able to do what they do more efficiently and effectively than local non-MNCs. One thing the Company did very well was to be a monopoly that enabled it to set its own prices in the market in a deviation from the simple nostrums of perfect competition (Buckley, 2003). The Company also developed managerial expertise through its networks of factors on the ground across those parts of India it came to dominate. The operating costs in salaries from the central office in London were minimal. 'It ruled millions of people from a tiny headquarters, staffed by 159 in 1785 and 241 in 1813' (The Economist, 2011). Of course, given the speed of 
communications, the central managers could hardly 'manage' the regional factories;

hence, the latter had considerable autonomy.

Employees were allowed not only to choose how to fulfil their orders, but also to trade on their own account. This ensured that the Company was not one but two organisations: a hierarchy with its centre of gravity in London and a franchise of independent entrepreneurs with innumerable centres of gravity scattered across the east. Many Company men did extremely well out of this "tight-loose" arrangement, turning themselves into nabobs, as the new rich of the era were called, and scattering McMansions across rural England (The Economist, 2011).

The Company was adept at overcoming governmental regulations: moving inside national territories allowed them either to accord with local laws that might limit their capacity to trade as outsiders or, through combinations of soft and hard power, bend the rules. The Company developed superior organizational and strategic attributes in extracting goods, collecting taxes and delivering armed services that could be readily implanted into new contexts of rule from the bridgeheads.

Comparative institutional advantage

The Company had to develop, especially in its earliest days, what sociologists would call 'embeddedness' - deep immersion in local laws, institutions, cultures, norms etc. The Company men had a great deal of learning to do, initially, as Darwin (2012, p. 52) explains:

To avoid giving offence, they must learn the court rituals and diplomatic procedures of those rulers whose favour thy sought. They could hardly ignore the political and geographical upheavals within and between the great Asian states that might settle their fate one way or the other. They had to know something of the religions and cosmologies of the cultures that lapped around them, or risk outrage, expulsion and worse.

The Company was adept at these adjustments, at least before Cilve's victory at Plassy, 'a victory that owed more to treachery, forged contracts, bankers and bribes than military prowess (Dalrymple, 2015). After Plassy the hubris of rulership and the arrogance of cultural domination set in, when the Company men began to see themselves as masters of the large chunk of the known universe they controlled. In their own imagination they ruled far and wide over a great mass of peoples and land; in reality, as Darwin (2012, p. 52) suggests, they constituted a 'microscopic minority on the edge of vast civilizations', subject to 'the magnet-like force of glamorous 
rulership, all-embracing religions and subtle philosophies ... more like midgets than masters'.

Not only did the Company men have to learn new ways of being strangers in a strange land they also innovated ways of keeping in touch with their old world, if only at a considerable distance. 'The Company pioneered the art of government by writing and government by record, to paraphrase Burke. Its dispatches to and from India for the 15 years after 1814 fill 12,414 leather-bound volumes. It created Britain's largest cadre of civil servants, a term it invented' (The Economist, 2011). It also operated its civil service on merit principles that John Stuart Mill (1848), one of its employees, was to distil as fundamental principles of political economy that had an immense influence globally on the field of public administration.

The key institutional innovation in the Company's strategy that made all other innovations possible was arbitrage. Arbitrage is the practice of profiting from differences in costs and process across borders - basically buying where prices are lowest, selling where prices are greatest. The Company was an extraordinarily effective vehicle for integrating the extraction and distribution of goods on this basis. To be able to exploit the global opportunities for profit that arbitrage offers, a MNC needs strategies that enable it to have maximal flexibility location, know-how and knowledge, as well as the ability to react rapidly to threats and opportunities. Reactive ability will be limited by the necessity of abiding by the rules of the states in which they invest; under these circumstances, a temptation is to either subsume the state through soft power or defeat it through hard power, at both of which the Company was skilled. It could be said that an early form of governance and organizational capability systems (see Whitley 2000) of liberal market economies could already be found in the first MNC. It was not so much that the Company was implementing a liberal economic vision conceived imperially as that it pioneered strategies that increasingly economically liberal states would adopt. Victorian England, with its perpetual struggles over the Corn Laws, was hardly a liberal economic state.

\section{The end of the East India Company}

Clive's 1757 victory at Plassey denoted both the high point of the Company's success in India and the beginning of its slow downfall. Contemporaries likened Clive and others of his ilk to unscrupulous conquistadores, butchering, plundering and looting with abandon. The effective subjugation of Bengal after Plassy produced a 
guaranteed income from Bengal's taxpayers while involving the Company

increasingly less in trade and more in raising revenues through taxes. Administrative obligations overtook its trading instincts; routinized raising of revenue increasingly displaced entrepreneurial commerce.

Only seven years after the granting of the Diwani, when the company's share price had doubled overnight after it acquired the wealth of the treasury of Bengal, the East India bubble burst after plunder and famine in Bengal led to massive shortfalls in expected land revenues. The EIC was left with debts of $£ 1.5 \mathrm{~m}$ and a bill of $£ 1 \mathrm{~m}$ unpaid tax owed to the Crown. When knowledge of this became public, 30 banks collapsed like dominoes across Europe, bringing trade to a standstill.

In a scene that seems horribly familiar to us today, this hyper-aggressive corporation had to come clean and ask for a massive government bailout. On 15 July 1772, the directors of the East India Company applied to the Bank of England for a loan of $£ 400,000$. A fortnight later, they returned, asking for an additional $£ 300,000$. The bank raised only $£ 200,000$. By August, the directors were whispering to the government that they would actually need an unprecedented sum of a further $£ 1 \mathrm{~m}$. The official report the following year, written by Edmund Burke, foresaw that the EIC's financial problems could potentially "like a mill-stone, drag [the government] down into an unfathomable abyss ... This cursed Company would, at last, like a viper, be the destruction of the country which fostered it at its bosom." (Dalrymple, 2015).

It was not debt, however, that destroyed the Company. The future of India and the demise of the Company were signalled by the Sepoy Mutiny of 1857, which sparked the Great Rebellion - or Indian Mutiny as Victorians called it - that saw the end of the Company's rule and the beginnings of British Governmental rule proper. Hard power was required. Ninety thousand soldiers from the British Army were stationed in India. After the rebellion, fearing the insurgency of the locally sourced troops, the British state, which had now taken over the administration of India from the wound-up Company, increased the garrison threefold from its pre-Rebellion strength, such that a ratio of one British soldier to every two Indian recruits applied, all supported at the Indian tax payers' expense (Darwin 2012, p. 132). The great adventure of the English-speaking world's first commercial MNC was over.

\section{What can we learn from the East India Company about MNCs?}

Morgan and Kristensen (2006) offer a powerful corrective to some of the overly rationalistic and economistic views in the international business, strategy and multinationals literature. 
[T] he MNC as a totality may be seen as a highly complex configuration of ongoing micro-political power conflicts at different levels in which strategizing social actors/groups inside and outside the firm interact with each other and create temporary balances of power that shape how formal organizational relationships and processes actually work in practice. Institutions enter into these processes, firstly as co-constitutors of the set of actors/groupings and their mutual roles and identities, secondly as forms of restriction on the choices actors make, thirdly as resources that empower actors and finally as rule-givers for the games that emerge (Morgan and Kristensen 2006, p. 1473).

Although written by contemporary organization theorists the analysis applies aptly to the East India Company. Although it was an organization in a commercial sense its strategy was not something decided at the hub and then distributed to the peripheries. Peripheries are not passive vessels: they do not always wait to see what gets poured into them or is denied them. The Company's periphery comprised networked entities embedded in a complex network of partnerships and subjugations in which the portfolio of allies was constantly changing due to shifting requirements for resources. The Company's organizational boundaries were fluid and volatile incorporating trade, tax collection and suppression of insurrection. In consequence, its mandate was shifting not stable, redefining the boundaries of its operations as events unfolded. The Company's capacity to manage these blurred boundaries and networks successfully represented a critical strategic ability; the Great Rebellion signalled that this ability had become over-extended.

There are many strategic as well as practical aspects of inter-organizational collaboration that are important to consider in alliances and networks. To begin with, firms have to assess whether collaboration is a viable strategy to gain access to important resources, then they have to find suitable partners, negotiate terms and conditions, implement governance structures, processes and policies, and choose and integrate the management and team members. Ultimately, they need to know when to best exit partnerships, the test that the Company failed.

Despite its failure under the weight of the problems it created for itself and the British government, the Company prefigures many lessons for MNCs. It teaches the importance of expatriate managers becoming embedded - but not too embedded. It teaches the importance of expatriate managers becoming entrepreneurial - but not so entrepreneurial as to inflame jealousies at home through the flaunting of wealth 
gained overseas, becoming labelled as 'nabobs' ${ }^{3}$. It teaches the virtues of efficient and lean administration - but not so lean as to be unable to deal with local difficulties without calling on state aid. It demonstrates the importance on MNC mandate and how easy it is for this to escalate and shift, often imperceptibly and surreptitiously. It teaches that the central business of MNCs is politics by other means - whether by bribery, corruption, inducements, favours - soft power - or through acting as a quasi state, enforcing rules and its conception of local order. It teaches the importance of keeping the home government on side: returned nabobs such as Clive used their wealth to bribe MPs and buy parliamentary seats in Rotten Boroughs. It teaches about the shifting balance of power between centre and periphery endemic to all MNCs. It teaches the importance of serendipity, randomness and events in the life of great companies: had not the Portuguese and Dutch got further east first the East India Company would never have become so entrenched in India. Had it not come to dominate the Indian trade then it might not have become so implicated in the trade of smuggling opium from India into China. Had Clive not won victory at Plassy the Company might have remained a commercial rather than taxing and administrative enterprise. It reminds us that the East India Company failed one really important test: when best to exit.

It could be objected that the militarization of the Company and its role in exerting sovereignty over conquered territory is far from contemporary practice but recall the Second Gulf war in Iraq in which companies such as Blackstone became sub-contracting warriors on behalf of the US state and its occupying forces. In the nineteenth century wars were fought over opium; in the twenty first century they are fought over oil. The commodities change; the global politics and the role of multinationals do not. The lines between commerce and militarism were fudged and blurred by the Company in a precedent that should inspire all companies in the contemporary military-industrial complex.

The East India Company was, indeed, a harbinger of the modern world; it created the template for a thoroughly modern MNC. In destroying the Indian cotton industry with what Marx and Engels (1844) referred to as the artillery of cheap prices, a lesson that modern multinationals have learnt in diverse product markets in

${ }^{3} \mathrm{~A}$ nabob was an Anglo-Indian term that referred an East India Company servant who had become wealthy through corrupt trade and other practices. 
commodities in the post war era, most recently by virtue of extensive subcontracting through supply chains rooted in the very territories that the Company and its rivals once dominated.

They dominated these territories not only through economic trade. The Company's power and authority in the Indian subcontinent relied upon garrison, in which the vast majority of troops were indigenes, commanded by a small cadre of British officers. As Darwin argued, because of the danger that British officials might be drawn into partnership with local Indian networks of influence, as well as the fear of rebellion that materialized and ended the Company in 1857, "no white person in India could escape the constant reminder - by history, myth and commemoration that racial solidarity was the price of survival'. The Passage to India, as Forster so skilfully explored, placed the white British subject in a web of institutionalized racism, in all of its complexity, that reached everywhere that these subjects traded, conquered and settled. Imperialism was a state of mind as much as it was a garrison state. Most significantly, as the character of Dr Aziz shows in Forster's remarkable novel, it was not a state of mind that constituted a social relation: the power relations that the Company exemplified produced patterns of subordinated consciousness just as much as they produced the arrogance of rulership.

\section{Conclusion}

In conclusion, there are uncanny parallels with the experiences of the Company in the sub-continent and present day adventures. It was the Company's fear of growing Russian influence that led them to invade Afghanistan in 1839 and occupy Kabul until 1842. An army of 20,000 soldiers and 38,000 auxiliaries and camp followers was involved. Life in occupied Kabul was sweet for the Company men but expensive for the Company: many bribes to warlords were necessary to maintain the peace and as the costs mounted the bribes slowed. In 1842 one of these warlords, Akbar Khan, began to organize tribal groups dissatisfied with the cessation of bribes from the Company under the pressure of commercial exigency. Akbar Khan laid siege to Kabul and negotiated an orderly retreat for the Company through the Hindu Kush to Jalalabad for the military and camp followers, with the Company leaving for Jalalabad with 16,000 people. After having laid siege to Kabul, Akbul Khan destroyed the garrison facilities and killed those left behind. Of the 16,000 who trekked to Jalalabad only one European and a few Indian sepoys survived as the tribesmen cut 
them down in the passes and hills. The costs and perils of military and commercial adventure in Afghanistan is one lesson still to be learned, as is humility before the arrogance of rulership.

I began this chapter by asking what kind of multinational the East India Company was and the extent to which it prefigured more contemporary forms of multinational enterprise. The answer is evident: it was an extraordinarily exploitative multinational with a very flexible focus: it was a trader, merchant, mercenary, military force and civil administrator, a pioneer bureaucracy as well as being a lean operation. In contemporary terms some of its activities prefigure the privatization of military activities by multinationals such as Blackwater, which after the Iraq War morphed into Academi or firms such as Constellis. In other respects it bears more resemblance to major drug cartels such as Mexico's Sinaloa Cartel or the co-involvement of the CIA and the Nicaraguan Contras. In yet other respects it resembles Amazon, trading in a vats range of commodities. Whether considered as a multinational drug dealer, multinational security services provider, or multinational merchant in commodities it is evident that the East India Company prefigured many elements of multinational practice, as this chapter has proposed. 


\section{References}

Baysinger, B. (1984) Domain Maintenance as an Objective of Business Political Activity: An Expanded Typology, Academy of Management Review, 9(2): 248258.

Becker-Ritterspach, F., Lange, K. \& Lohr, K. (2002) Control Mechanisms and Patterns of Reorganization in MNCs. In M. Geppert, D. Matten, and K. Williams (Eds.) Challenges for European Management in a Global ContextExperiences from Britain and Germany, Basingstoke: Palgrave, pp 68-95.

Birkinshaw, J., \& Ridderstråle, J. (1999) Fighting the Corporate Immune System: A Process Study of Subsidiary Initiatives in Multinational Corporations, International Business Review, 8(2): 149-180.

Blumentritt, T. P. (2003) Foreign Subsidiaries' Government Affairs Activities: The Influence of Managers and Resources, Business \& Society, 42(2): 202-233.

Boddewyn, J. (1988) Political Aspects of MNE Theory, Journal of International Business Studies, 19(3): 341-363.

Boddewyn, J. J. (1975) Corporate External Affairs: Blueprint for Survival, New York: Business International Corporation.

Boddewyn, J. J. (1993) Political Resources and Markets in International Business:

Beyond Porter's Generic Strategies, Research in Global Strategic Management, 4: 83-99.

Boddewyn, J. J. \& Brewer, T. L. (1994) International-Business Political Behavior:

New Theoretical Directions, Academy of Management Review, 19(1): 119-143.

Bouquet, C. \& Birkinshaw, J. (2008) Managing Power in the Multinational

Corporation: How Low-Power Actors Gain Influence, Journal of Management, 34(3): 477- 508.

Buckley, P. (2003) Globalization and Multinational Enterprise. In D. Faulkner and A. Campbell (Eds.) The Oxford Handbook of Strategy, Oxford: Oxford University Press.

Clegg, S.R., Courpasson, D. \& Phillips, N. (2006). Power and Organizations.

London: Sage. 
Crozier, M. \&Friedberg, E. (1980) Actors and Systems: The Politics of Collective Action, Chicago: University of Chicago Press.

Cyert, R. M. \& March, J. G. (1963) A Behavioral Theory of the Firm, Englewood Cliffs, New Jersey: Prentice-Hall.

Dalrymple, W. (2015) The East India Company: The original corporate raiders, The Guardian, March 4, 2015.

Darwin, J. (2012) Unfinished Empire: The Global Expansion of Britain. London: Bloomsbury Press.

de Vries, J. \& van der Woude, A (1997) The First Modern Economy: Success, Failure, and Perseverance of the Dutch Economy, 1500-1815. New York: Academic Press.

Dörrenbächer, C. \& Gammelgaard, J. (2006) Subsidiary Role Development: The Effect of Micro-political Headquarters-Subsidiary Negotiations on the Product, Market and Value-added Scope of Foreign-owned Subsidiaries, Journal of International Management, 12(3): 266-8.

Dörrenbächer, C. \& Geppert, M. (2009) Micro-Political Strategies and Strategizing in Multinational Corporations: The Case of Subsidiary Mandate Change. In L. A. Costannzo, and R. B. MacKay (Eds.) Handbook of Research on Strategy and Foresight, Cheltenham: Edward Elgar, pp. 200-218.

Eden, L. \& Molot, M. A. (2002) Insiders, Outsiders and Host Country Bargains, Journal of International Management, 8(4): 359-388.

Forster, E. M. (1924) A Passage to India. New York: Harcourt.

Foster, W. (1933) England's Quest of Eastern Trade, London: A \& C Black. Gammelgaard, J. (2009) Issue Selling and Bargaining Power in Intrafirm

Competition: The Differentiating Impact of the Subsidiary Management Composition, Competition and Change 13(3): 214-228.

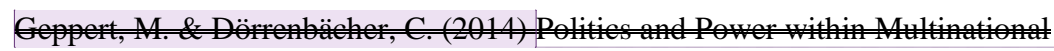

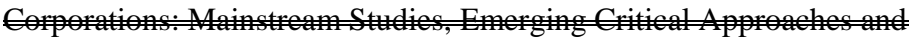

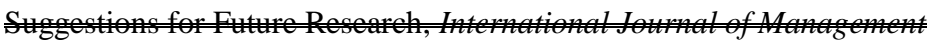

R $16(2), 226244$ DOI: 10.1111 ijim. 12018.

Harzing, A. W. (1999) Managing the Multinationals: An International Study of

Control Mechanisms, Cheltenham, United Kingdom: Edward Elgar.

Hiromu, N. (2009) The Factories and facilities of the East India Companies in Surat:

Locations, Building Characteristics and Ownership, chapter 10 in Masaashi, H. 
(ed.) Asian Port Cities 1600-1800: local and Foreign Cultural Interactions, Tokyo and Singapore: Kyoto University Press in association with National University of Singapore Press.

Johnson, G., Scholes, K. \& Whittington, R. (2008) Exploring Corporate Strategy, London: Pearson.

Kalyvas, S. N. (2006) The Logic of Civil War, Cambridge: Cambridge University Press.

Keay, J. (1993) The Honourable Company: A History of the English East India Company. London: HarperCollins.

Keith A. B. (1922) Speeches and Documents on Indian Policy 1750-1921, Oxford: Oxford University Press.

Lovell, J. (2011) The Opium War: Drugs, Dreams and the Making of China. London: Picador.

Luo Y. (2005) Toward coopetition within a multinational enterprise: a perspective from foreign subsidiaries, Journal of World Business, 40: 71-90.

March, J. G. (1962) The Business Firm as a Political Coalition, Journal of Politics, 24(4): 662-678.

Markides, C. (2000) All the Right Moves: A Guide to Crafting Breakthrough Strategy, Vol. 1, Boston, Massachusetts: Harvard Business School Press.

Marx, K. \& Engels, F. (1844/1968) The Manifesto of the Communist Party. Moscow: Progress Publishers.

Mill J. S. (1848/1909) Principles of Political Economy with some of their Applications to Social Philosophy, ed. William James Ashley, London: Longmans, Green and Co., 1909, $7^{\text {th }}$ edition; accessed at http://oll.libertyfund.org/titles/101 on 18.05.2014.

Moran, T. (1985) Multinational Corporations and the Developing Countries: An Analytical Overview. In T. Moran (Eds.) Multinational Corporations, The Political Economy of Foreign Direct Investment, Lexington, MA: D.C. Heath \& Co, pp 3-24.

Morgan, G. (2011) Reflections on the macro-politics of micro politics. In

Dörrenbächer, C. and Geppert, M. (eds) (2011) Politics and power in the Multinational Corporation: The Role of Institutions, Interests and Identities. Cambridge: Cambridge University Press. 
Morgan, G. (2001) The Multinational Firm: Organizing Across institutional and national divides. In G. Morgan,P. H. Kristenssen and R. Whitley(Eds.) Oxford: Oxford University Press, pp 1-24.

Morgan, G. \& Kristensen, P. (2006) The Contested Space of Multinationals: Varieties of Institutionalism, Varieties of Capitalism, Human Relations, 59(11): 1467 1490.

Pfeffer, J. \& Salancik, G. R. (1974) Organizational Decision Making as a Political Process: The Case of a University Budget, Administrative Science Quarterly, 19(2): 135-151.

Robins, N. (2006) The Corporation that Changed the World: How the East India Company Shaped the Modern Multinational. London: Pluto Pres.

Rugman, A. M., \& Verbeke, A. (1993) Generic Strategies in Global Competition. In A. M. Rugman and A. Verbeke (Eds.) Research in Global Strategic Management: Global Competition Beyond the Three Generics, Vol 4, Greenwich, Connecticut: JAI Press, pp. 3-15.

Sharpe, D. R. (2001) Globalization and Change: Organizational Continuity and Change within a Japanese Multinational in the UK. In G. Morgan, P. Kristensen, and R. Whitley (Eds.) The Multinational Firm: Organizing across Institutional and National Divides, Oxford: Oxford University Press, pp. 196222.

Suchman, M. C. (1995) Managing Legitimacy: Strategic and Institutional Approaches, Academy of Management Review, 20(3): 571-610.

The Economist (2011) The East India Company: The Company that ruled the waves, The Economist, December 17, 2011, accessed at http://www.economist.com/node/21541753 on 18.05.14

Vernon, R. (1971) Sovereignty at Bay, New York: Basic Books.

Wheeler, J. T. (1861) Madras in the Olden Times: A History of the Presidency 16391702 from Official Records. Madras: Higginbotham.

Whitley, R. (2000) Divergent Capitalisms: The Social Structuring and Change of Business Systems. Oxford: Oxford University Press.

Young, I. M. (2003) From Guilt to Solidarity: Sweatshops and Political Responsibility, Dissent 50(2), 39-44. 